\title{
FAMILY NURTURE IN THE SOCIAL SKILLS DEVELOPMENT OF CHILDREN WITH INTELLECTUAL DISABILITIES THROUGH DAILY ACTIVITIES
}

\author{
Mumpuniarti Mumpuniarti *, Gena Diniarti, Wening Prabawati, Suparno Suparno \\ Universitas Negeri Yogyakarta, Yogyakarta, Indonesia \\ * e-mail: mumpuni@uny.ac.id
}

\begin{abstract}
In the time of COVID-19 pandemic, social restriction inhibits social skills. This research examines family nurturing in facilitating the social skills development, parents' inclination in facilitating nurturing, and different intensities in nurturing the social skills development of children with intellectual disabilities (ID). This research subjects included eight parents of 5-7-year-old children with mild ID who were pursuing preschool special education. It employed a qualitative approach. Data collection was performed through interviews guided with a close-ended questionnaire on 11 social skills categories. Reasons for the development of each social skills category were to be revealed through an open-ended questionnaire. Data analysis involved the categorization of social skills in relation to daily living activities in the family. It was found that the social skills that might be developed through daily living activities in the family were the social skills performed through activities with family. Parents' ability to stimulate the social skills of children with ID tended to be concrete in nature and dependent on other people as models and the intensity on the presence of others to support as media.
\end{abstract}

Keywords: activities in family, social skills of children with intellectual disabilities.

\section{PENGASUHAN KELUARGA UNTUK PERKEMBANGAN KETERAMPILAN SOSIAL ANAK DISABILITAS INTELEKTUAL MELALUI AKTIVITAS SEHARI- HARI}

\begin{abstract}
Abstrak: Pandemi COVID-19 di tahun 2020 merupakan masa diperlukannya pembatasan, sehingga meng-hambat keterampilan sosial. Penelitian ini mengkaji peran pengasuhan keluarga dalam memfasilitasi pengembangan keterampilan sosial; kecenderungan orang tua dalam memfasilitasi pengasuhan; dan intensitas yang berbeda dalam membina perkembangan keterampilan sosial anak yang memiliki disabilitas intelektual (intellectual disability, ID). Subjek penelitian ini adalah delapan orang tua dari anak usia 5-7 tahun dengan ID ringan yang sedang menempuh pendidikan khusus prasekolah. Ini menggunakan pende-katan kualitatif. Pengumpulan data dilakukan melalui wawancara yang dipandu dengan kuesioner tertutup pada 11 kategori keterampilan sosial. Alasan pengembangan setiap kategori keterampilan sosial diungkap-kan melalui kuesioner terbuka. Analisis data melibatkan kategorisasi keterampilan sosial dalam kaitannya dengan aktivitas kehidupan sehari-hari dalam keluarga. Hasil penelitian menemukan bahwa keterampilan sosial yang dapat dikembangkan melalui kegiatan seharihari dalam keluarga adalah keterampilan sosial yang dilakukan melalui kegiatan bersama keluarga. Kemampuan orang tua untuk mendorong tumbuhnya keterampilan sosial anak dengan ID cenderung bersifat konkret dan bergantung pada orang lain sebagai model, dan intensitas dalam memelihara kehadiran orang lain untuk mendukung sebagai media.
\end{abstract}

Kata Kunci: kegiatan dalam keluarga, keterampilan sosial anak hambatan intelektual.

\section{INTRODUCTION}

Social skills are useful for an individual to interact with others effectively. These skills are also important for the sustenance of relationship between individuals by way of cooperation and behavioral adjustment in a given context or situation in which the relationship is taking place (Halle \& Darling-Churchill, 2016). Social skills are involved in interactions between one indi- vidual and another, and they are also needed for these individuals to conduct activities together, allowing the establishment of a sense of belonging (Garrote et al., 2017). This sense of belonging is necessary for one to share and communicate feelings with another when conducting activities. This implies that those who are engaged in social interactions will try to maintain the relationship established between them. This sense of belonging and sharing should be built from an 
early age as it sets the ground for further development into adulthood (Taylor et al., 2017). Social skills also steer the success of individuals in their adult lives as the quality of cooperation and interaction with others will be accepted in the social context, and this acceptance will lead to the acceptance of all endeavours socially (Adela et al., 2011). The problem that occurs is that the family has not optimized the social development of ID children. It is because many families who have ID children have psychological problems (Allen, 2008; Boehm \& Carter, 2016; Nastiti \& Purwanta, 2019; Tudor \& Lerner, 2015). As a result, the social development of ID children does not develop optimally.

Individuals with ID are a group with an inhibition to develop social skills. This inhibition refers to cognitive limitations which undermine one's ability to decipher symbols related to forms of social interaction (Rani \& Keshwal, 2016). Individuals with ID have limitations in intellectual and, at the same time, adaptive behaviour functions. These limitations also appear in slow social skills learning as individuals with ID often fail to understand meaningful interactions (Rani \& Keshwal, 2016). These meaningful interactions must still be practiced in real activities and contexts in daily life. Real contexts become concretely meaningful as they are experienced and undertaken directly through habituation. Real contexts in daily life can be acquired in the family (Adela et al., 2011; Dewi et al., 2018; King et al., 2017; Mamta Rani \& Hemant Singh Keshwal, 2016). Daily activities in the family also offer a solution during the implementation of social distancing over the COVID-19 pandemic (Nature, 2020). This pandemic is a problem for children as they are now prevented from exploring social skills learning through activities with their peers. Activities in the family, thus, become relied upon in the stimulation of children's development, especially in the case of children with ID.

The adverse effects of the COVID-19 pandemic set limitations to children's development in playing and interacting with their peers (Yoshikawa et al., 2020). This restriction reduces children's opportunities to play outside, explore the environment, and gain the benefits of motor motions and social skills (Nature, 2020). Minimal outdoor activities urge the family to provide opportunities for social development through social activities in the family (Shepley et al., 2018). Social skills for children with ID should be encouraged since early on as these social skills serve as a foun-dation for future life skills (Callahan et al., 2017; Ferreira et al., 2019; Mamta Rani \& Hemant Singh Keshwal, 2016; Shepley et al., 2018; Taylor et al., 2017). The cognitive limitations of children with ID in learning social skills should be improved through the direct practice of the activities learnt (Spriggs et al., 2017). These learning activities can be provided in the family. This will also compensate for the minimal play activities with peers due to the COVID-19 pandemic. In-family activities are a primary facility to recognize significant others as a foundation for the acquisition of social skills (Berns, 2010). The cognitive limitations urge the family to guide adaptive behaviours, including social skills, on a daily basis (Hallam, 2010; Tassé et al., 2012; Vuijk et al., 2010).

Daily activities in the family are expected to facilitate social skills development as the atmosphere and situation in the family serve as value symbol connectivity of the activities learnt (Lussier-Desrochers et al., 2014). Connectivity offers a solution to the limitations in functioning and skills enhancement faced by individuals with intellectual disabilities. Connectivity contains highly concrete and contextual activity symbolism, allowing the activities to be learnt by children with intellectual disabilities from early on at home (Rani \& Keshwal, 2016). Home activities such as playing, cleaning the environment around the house, preparing meals, eye contact, and communication will reflectively form social skills categories that are directly acceptable to the family members. The nurturing effect of social skills will be directly derived from activities in the family in relation to such social skills because unending family nurturing will train children with ID to learn to form social skills which are adaptable for the family members (Smith et al., 2012). Previous research backs this up, saying that activities in the family for social skills development serve as a basis for life skills and independence during adulthood (Callahan et al., 2017; Domitrovich et al., 2017; Rock \& Crow, 2017).

Social skills development in children with ID from an early age occupies an urgent position, as it is beneficial in shaping social acceptance in the society in which they live. This development includes the areas of cognitive, social and emotional, and motor skills. It requires nurturing from early on for these skills to be well-prepared for use into adulthood (Lussier-Desrochers et al., 2014; McLeod et al., 
2017; Mihaela, 2015; Tarasova, 2016). Parenting from the family also has implications for coping strategies and involvement of all family members (Diana et al., 2021; Mujahidah et al., 2019; Muthmainah et al., 2021). This is because the social development of ID children requires a concrete social atmosphere and family strategies in overcoming problems.

Social skills in children with ID need nurturing because their cognitive limitation requires modelling and encouragement in real-time at the moment when a relevant event takes place. Behavioural problems also accompany the condition of children with ID, necessitating a strong effort to nurture their children's social skills (Blacher et al., 2009). It is important for the parents to provide opportunities for these children with ID to learn social skills. The accompaniment of strong nurturing from the parents to the children with ID's social skills learning is helpful in reducing the behavioural problems present in the children (Boehm \& Carter, 2016). Children with ID who have achieved social skills will expand their access to sources of various life challenges in the communities where they live. The behavioural problems will be eliminated as their need for sources of learning has been fulfilled through concrete examples and experiences. How to overcome living problems through social interactions is learnt through the practice under the parents' nurturing (Sterkenburg et al., 2008). The elimination of these behavioural problems is made possible by social contact derived during social skills learning. In sum, social skills have an urgency for children with ID because it is useful for the preparation of skills necessary in the adult life in the community, the reduction of accompanying behavioural problems, and achievement of access to the skills needed to overcome life challenges collectively in the context of social relationship with others. This study seeks to investigate the nurturing of social skills development in children with ID. This study addresses these questions: (1) what forms does family nurturing take in facilitating the social skills development of children with ID through daily living activities; (2) how is parents' inclination in facilitating nurturing of the social skills development of children with ID; and (3) does each family have a different intensity in nurturing the social skills development of children with ID.

Social skills in children with ID nurtured in daily living activities in the family were investigated through early-age social skills meas- uring instrument developed by Hurlock (2001) in his book Child Development. The eleven positive social skills categories were selected and modified in the description of the social skill characteristics in eleven categories. These patterns include cooperation, competition, generosity, desire for social acceptance, sympathy, empathy, dependence, amiability, unselfishness, emulation, and attachment behaviour. The eleventh skill was investigated in terms of development by way of family nurturing.

\section{METHODS}

This research used a qualitative approach and collected data through interviews with parents of 5-7-year-old children with ID. This research specifically describes family contribution in nurturing the social skills development of children with ID through daily living activities in the family. The subjects of this research were eight parents of 5-7-year-old children with intellectual disabilities. The subjects were purposively selected under the criterion that they were parents of early-age children with intellectual disabilities who were proactive and fully aware of nurturing their children's development. Currently, the children of the selected parents are attending special needs schools.

Data were collected through interviews which were guided by a close-ended instrument. The respondents were requested to choose between two options of statements describing 11 social skills categories. Then, they were asked to choose some statements on the forms of activities in a family that support the nurturing of the social skills development of children with intellectual disabilities at home.

The interview instrument is taken from the Hurlock' (2001) social skills. There was a total of 11 items, each of which was described its characteristics. The patterns picked were positive. In this research, the description of each item of social skill behaviour was reverified according to the cognitive limitations of children with ID. If there was any incompatibility, the modification was made. Other categories are presented in the research results section. The categories selected were the positive ones as the nurturing of social skills aims to form positive behavioural patterns. Negative behavioural patterns are the effect of the behavioural problems of children with ID, which must be eliminated.

Data analysis was based on the description of each category, and each category was compared against another (Denzin \& Lincoln, 
2008). Categorization was aimed for the drawing of inference from each social skills pattern, while comparison was aimed for the determination of which one of the daily living activities was the best way of family nurturing. The comparison was based on the parents' statements regarding their facilitation in daily living activities in the family.

Data analysis was conducted in the following steps: data validation, interpretation of data themes/description about forms nurturing family, inclination in facilitating the nurturing, and intensities in the nurturing of the social skills development. Furthermore, the interpretation of the data is taken as an inference from the research findings. The inference process was done through categorization and comparison. Comparison of the form of family care that is often done and not done is regarded as the most intensive inference in nurturing.

\section{FINDING AND DISCUSSION Finding}

Forms of family nurturing for the social skills development of children with ID through daily living activities

The results of forms of family nurturing for the social skills development of children with ID are shown in Table 1,2,3 and 4. These tables show the form of caring for each aspect of social skills developed for children with ID. Each table describes one aspect of ID social skills and the form of nurturing performed by eight subjects (families of ID children). Furthermore, eight subjects in doing every aspect of social skills of ID children were taken inference. For this reason, the results of the 11 social skills inference form of care are the results of this study and are presented as follows (Table 1).

Family's inclination in facilitating the nurturing of the social skills development of children with ID

The eight subjects' inclination in nurturing the social skills development of children with ID was identified from the inference of each skills category. Meanings were derived from the inferences and then compared in order to draw conclusions on parents' inclination in facilitating the nurturing of the social skills development of children with ID. The meaning of facilitating family nurturing for social development for ID children includes parents tended to perform nurturing through play; nurturing through daily liv- ing activities in the domestic area in the family was minimal, the majority of the parents were against developing their intellectually disabled children's competitive skills development. This was because they viewed competitive skills as maladaptive social skills. However, some opined that competition could be directed toward making achievements. Concrete behavioural examples and relevant social situations are needed, i.e., other individuals are needed for modelling purposes. They were mingling with the children's closest social groups and sympathizing with the predicaments faced by closest ones. The parents found it difficult to train empathizing skills as these skills would require the ability to read others' facial expressions. No intensive training was performed on these skills because early-age children with ID were seen as not having developed the ability to interpret others' facial expressions. This skill is abstract in nature, and it requires relevant social situations. Relevant social situations are required to train altruist behaviour. There were some behaviours others would emulate. There were social situations that allowed one to be attached to others psychologically.

These 11 meanings are the result of a description of the tendency of parents to take care of the social skills development of ID children. This is explained in Table 2. Thus, family's inclination in nurturing the social skills development of children with ID includes the actions of the parents of the ID consisting of parents who tended to perform nurturing through play, while nurturing through daily living activities in the domestic area in the family was minimal. The majority of the parents were against developing their intellectually disabled children's competitive skills development. This was because they viewed competitive skills as maladaptive social skills. However, some opined that competition could be directed toward making achievements. The concrete behavioural examples and relevant social situations are needed, i.e., other individuals are needed for modelling purposes, mingling with the children's closest social groups, and sympathizing with the predicaments faced by closest ones. The parents found it difficult to train empathizing skills as these skills would require the ability to read others' facial expressions. It was also found there was no intensive training performed on these skills because early-age children with ID were seen as not having developed the ability to interpret 
others' facial expressions. This skill is abstract in nature, and it requires relevant social situations. The relevant social situations are required to train altruist behaviour. There were some behaviours others would emulate, and there were social situations which allowed one to psychologically be attached to others.

Variation in intensities in the nurturing of the social skills development of children with ID

Information regarding nurturing intensities was synthesized from the meanings of the parents' nurturing inclination. The comparison was then conducted against the meanings to determine whether or not the nurturing conducted by the parents in 11 social skills categories among children with ID was intensive.

From the interviews with the subjects, there would be a tendency for abstract social skills to be non-intensively trained. These skills included those belonging to the desire for social acceptance, sympathy, empathy, dependence on others, and amiability categories. No intensive nurturing was conducted on these five categories of skills as they were abstract in nature. Yet, the parents still made some efforts to train their children in these categories if the situations were relevant or if there were people who were around to support as media.

In conclusion, the variation in nurturing intensities for each subject depended on how the subject regarded which of the categories of skills needed nurturing. The majority of the subjects saw competitive skills as negative, but there were some who considered them as positive in the context of achievements making. The way the subjects saw each category of skills relied on the cultures in which they lived. Varying nurturing intensities for each subject are described in Table 4.

Table 1. Forms of family nurturing for the social skills development of children with ID through daily living activities

\begin{tabular}{clc}
\hline Number & Social Skills Aspect & Description \\
\hline 1 & Cooperion
\end{tabular}

1. Cooperation

The majority of the parents stated that nurturing was provided when the children played with their siblings and neighbouring peers. One subject assigned his/her child with the task of sweeping the floor, and two subjects said that their children's only activity was studying with their assistance. Parents assigning their intellectually disabled children with domestic activities as part of daily living activities in the family was minimal. The use of these activities as a nurturing means for developing cooperative skills was still minimum.

2. Competion

Nurturing for competitive skills was dependent upon the parents' views on the competitive skill forms. One subject was the notion that competitive skills have an element of achievement. Hence he/she was in favour of nurturing through play, keeping in mind this very element of achievement. The majority of the parents, on the other hand, were against developing competitive skills, positing that this set of skills is something to be avoided. As a result, they do not have a tendency for these skills to be developed in their children. There was even an object which was protective toward his/her child.

3. Generocity Generosity for children with ID is abstract. Hence, nurturing this set of skills requires concrete modelling and habituation. Other individuals are needed to provide examples in sharing food, sharing tasks, and playing.

4. The desire for social acceptance:

The parents nurtured the desire to be accepted by others in the context of social relationships through mingling with the social groups closest to the children.

5. Sympathy

With regard to sympathy, the majority of the subjects conducted nurturing by encouraging their children with ID to sympathize with the problems faced by their closest ones. One subject still found it difficult to conduct nurturing for these sympathizing skills.

6. Empathy

These empathizing skills are difficult to learn as they require the children to understand the facial expressions of others, interpret language symbolism, and understand the feelings expressed by others. Abstract phenomena are extremely difficult for children with ID to learn. Yet, some subjects tried to train their children in reading the facial expressions of their closest ones. Two subjects said they did not provide nurturing in this category.

7. Dependence on oth- The skills to obtain help and attention from others were not too intensively 


\begin{tabular}{|c|c|c|}
\hline Number & Social Skills Aspect & Description \\
\hline & $\begin{array}{l}\text { ers to obtain help, } \\
\text { attention, and affec- } \\
\text { tion }\end{array}$ & $\begin{array}{l}\text { nurtured by the parents. This was because the parents perceived that their } \\
\text { intellectually disabled children were still unable to interpret the facial ex- } \\
\text { pressions of those around them and because the parents were inclined to al- } \\
\text { ways assist their children. }\end{array}$ \\
\hline 8. & Amiability & $\begin{array}{l}\text { Being friendly toward others for children with ID is an abstract skill. Due to } \\
\text { its abstract nature, this skill must be learnt in relevant social situations. One } \\
\text { subject felt that his/her child was still not ready for the training in this skill. }\end{array}$ \\
\hline 9. & Unselfishness: & $\begin{array}{l}\text { The parents trained this skill if the social situations/conditions required the } \\
\text { sharing of facilities or food. In the absence of these social situa- } \\
\text { tions/conditions, this skill could not be trained. }\end{array}$ \\
\hline 10. & Emulation & $\begin{array}{l}\text { Four subjects believed that their children emulated the events or deeds occur- } \\
\text { ring in their surroundings. In this, the parents did not purposively train their } \\
\text { children. Some subjects believed that their children emulated the activities of } \\
\text { their closest ones. }\end{array}$ \\
\hline 11. & Attachment & $\begin{array}{l}\text { The parents were aware that children with ID are social creatures. Hence, } \\
\text { this skill was already conditioned in relevant social situations with the chil- } \\
\text { dren's closest ones. }\end{array}$ \\
\hline
\end{tabular}

Table 2. Family's inclination in nurturing the social skills development of children with ID

\begin{tabular}{ccc}
\hline Number & $\begin{array}{c}\text { The social skills of } \\
\text { children with ID }\end{array}$ & Family nurturing \\
\hline & Coopration &
\end{tabular}

1. Cooperation

The majority of the parents conducted nurturing only through play with sibsweeping the floor, and two subjects said that their children's only activity was studying with their assistance.

Parents assigning their intellectually disabled children with domestic activities as part of daily living activities in the family was minimal. The use of these activities as a nurturing means for developing cooperative skills was still minimum.

2. Competion Nurturing for competitive skills was dependent upon the parents' views on the competitive skill forms. One subject was the notion that competitive skills have an element of achievement. Hence he/she was in favour of nurturing through play, keeping in mind this very element of achievement. The majority of the parents, on the other hand, were against developing competitive skills, positing that this set of skills is something to be avoided. As a result, they tended not to will this skill to be developed in their children.

3. Generocity Generosity for children with ID is abstract. Hence, nurturing this set of skills requires concrete modelling and habituation. Other individuals are needed to provide examples in sharing food, sharing tasks, and playing.

4. The desire for social The parents nurtured the desire to be accepted by others in the context of acceptance:

5. Sympathy social relationships through mingling with the social groups closest to the children.

With regard to sympathy, the majority of the subjects conducted nurturing by encouraging their children with ID to sympathize with the problems faced by their closest ones. One subject still found it difficult to conduct nurturing for these sympathizing skills.

6. Empathy These empathizing skills are difficult to learn as they require the children to understand the facial expressions of others, interpret language symbolism, and understand the feelings expressed by others. Abstract phenomena are extremely difficult for children with ID to learn. Yet, some subjects tried to train their children in reading the facial expressions of their closest ones. Two subjects said they did not provide nurturing in this category.

7. Dependence on oth- The skills to obtain help and attention from others were not too intensively ers to obtain help, attention, and affection nurtured by the parents. This was because the parents perceived that their intellectually disabled children were still unable to interpret the facial expressions of those around them and because the parents were inclined to always assist their children.

8. Amiability Being friendly toward others for children with ID is an abstract skill. Due to its abstract nature, this skill must be learnt in relevant social situations. One 


\begin{tabular}{cll}
\hline Number & $\begin{array}{c}\text { The social skills of } \\
\text { children with ID }\end{array}$ & \multicolumn{1}{c}{ Family nurturing } \\
\hline 9. & Unselfishness: & $\begin{array}{l}\text { subject felt that his/her child was still not ready for the training in this skill. } \\
\text { The parents trained this skill if the social situations/ conditions required the } \\
\text { sharing of facilities or food. In the absence of these social } \\
\text { situations/conditions, this skill could not be trained. }\end{array}$ \\
10. & $\begin{array}{l}\text { Four subjects believed that their children emulated the events or deeds } \\
\text { occurring in their surroundings. In this, the parents did not purposively train } \\
\text { their children. Some subjects believed that their children emulated the } \\
\text { activities of their closest ones. } \\
\text { The parents were aware that children with ID are social creatures. Hence, this } \\
\text { skill was already conditioned in relevant social situations with the children's } \\
\text { closest ones. }\end{array}$ \\
\hline
\end{tabular}

\section{Table 3. Intensities of the family's nurturing of the social skills development in early-age} children with ID

\begin{tabular}{|c|c|c|c|}
\hline Number & $\begin{array}{l}\text { The social skills of } \\
\text { children with ID }\end{array}$ & Description & $\begin{array}{c}\text { Conclusion of intensitas } \\
\text { Nurturing }\end{array}$ \\
\hline 1. & Cooperation & $\begin{array}{l}\text { Parents tended to perform nurturing through play. } \\
\text { Nurturing through daily living activities in the } \\
\text { domestic area in the family was minimal. }\end{array}$ & Intensive, through play \\
\hline 2. & Competition & $\begin{array}{l}\text { The majority of the parents were against develop- } \\
\text { ing their intellectually disabled children's compet- } \\
\text { itive skills development. This was because they } \\
\text { viewed competitive skills as maladaptive social } \\
\text { skills. However, some opined that competition } \\
\text { could be directed toward making achievements. }\end{array}$ & $\begin{array}{l}\text { Non-intensive, due to } \\
\text { negative view on these } \\
\text { skills }\end{array}$ \\
\hline 3. & Generosity & $\begin{array}{l}\text { Concrete behavioural examples and relevant so- } \\
\text { cial situations are needed, i.e., other individuals } \\
\text { are needed for modelling purposes. }\end{array}$ & $\begin{array}{l}\text { Intensive, with concrete } \\
\text { behavioural examples }\end{array}$ \\
\hline 4. & $\begin{array}{l}\text { The desire for so- } \\
\text { cial acceptance }\end{array}$ & $\begin{array}{l}\text { I was mingling with the children's closest social } \\
\text { groups. }\end{array}$ & Non-intensive \\
\hline 5. & Sympathy & $\begin{array}{l}\text { I sympathized with the predicaments faced by } \\
\text { closest ones. }\end{array}$ & Non-intensive \\
\hline 6. & Empathy & $\begin{array}{l}\text { The parents found it difficult to train empathizing } \\
\text { skills as these skills would require the ability to } \\
\text { read others' facial expressions. }\end{array}$ & Non-intensive \\
\hline 7. & $\begin{array}{l}\text { Dependence on } \\
\text { others to obtain } \\
\text { help, attention, and } \\
\text { affection }\end{array}$ & $\begin{array}{l}\text { No intensive training was performed on these } \\
\text { skills because early-age children with ID were } \\
\text { seen as having not developed the ability to inter- } \\
\text { pret others' facial expressions. }\end{array}$ & Non-intensive \\
\hline 8. & Amiability & $\begin{array}{l}\text { This skill is abstract in nature, and it requires rel- } \\
\text { evant social situations. }\end{array}$ & Non-intensive \\
\hline 9. & Unselfishness & $\begin{array}{l}\text { Relevant social situations are required to train } \\
\text { altruist behaviour. }\end{array}$ & $\begin{array}{l}\text { Intensive, if there were } \\
\text { others with whom the } \\
\text { children would share }\end{array}$ \\
\hline 10 . & Emulation & $\begin{array}{l}\text { There were some behaviours others would emu- } \\
\text { late. }\end{array}$ & $\begin{array}{l}\text { Intensive, if there were } \\
\text { others the children would } \\
\text { emulate }\end{array}$ \\
\hline 11. & Attachment & $\begin{array}{l}\text { There were social situations that allowed one to } \\
\text { psychologically be attached to others. }\end{array}$ & $\begin{array}{l}\text { Depending on the social } \\
\text { situation in which there } \\
\text { would be a person or } \\
\text { some people to whom the } \\
\text { children would be at- } \\
\text { tached }\end{array}$ \\
\hline
\end{tabular}

Table 4. Subjects' nurturing intensities in training the social skills in family

\begin{tabular}{cll}
\hline Subjects & \multicolumn{1}{c}{ Intensities } & \multicolumn{1}{c}{ Description } \\
\hline 1. & Two categories & Competitive skills and dependence on others, because the former were consid- \\
were not trained & ered negative, while the latter could only be trained in the presence of other
\end{tabular}




\begin{tabular}{cll}
\hline Subjects & \multicolumn{1}{c}{ Intensities } & \multicolumn{1}{c}{ Description } \\
\hline 2. & $\begin{array}{l}\text { Two categories } \\
\text { were not trained } \\
\text { One category was } \\
\text { not trained } \\
\text { Three categories } \\
\text { were not trained }\end{array}$ & $\begin{array}{l}\text { individuals with whom the children would interact. } \\
\text { Competitive and emulating skills, because these skills would require the pres- } \\
\text { Sympathizing skills because these skills are abstract in nature. }\end{array}$ \\
$\begin{array}{l}\text { Competitive skills, emulating skills, and attachment to others because these } \\
\text { skills would require the presence of others to support as media. }\end{array}$ \\
5. & $\begin{array}{l}\text { Two categories } \\
\text { were not trained }\end{array}$ & $\begin{array}{l}\text { Unselfishness and emulating skills because these skills would require the pres- } \\
\text { ence of other individuals to serve as objects (individuals who would receive the } \\
\text { children with ID's actions). }\end{array}$ \\
6. & $\begin{array}{l}\text { Two categories } \\
\text { were not trained }\end{array}$ & $\begin{array}{l}\text { Dependence on others and unselfishness should be trained when other individu- } \\
\text { als are around. }\end{array}$ \\
7. & $\begin{array}{l}\text { One category was } \\
\text { not trained }\end{array}$ & $\begin{array}{l}\text { Empathizing skills, because these skills are abstract in nature and would require } \\
\text { the ability to read others' facial expressions. } \\
\text { According to the subject, the child was still dependent and frequently in need of } \\
\text { his/her mother's assistance. }\end{array}$ \\
8. & $\begin{array}{l}\text { Six categories } \\
\text { were not trained }\end{array}$
\end{tabular}

\section{Discussion}

According to the subjects, the forms of family nurturing in facilitating the social skills development of children with ID through daily living activities. The activities were playing together, sharing toys in various activities and food, mingling with closest communities, emulating the behaviours of closest ones, sympathizing with the predicaments of others, and reading others' facial expressions. Only a small portion of the subjects conducted nurturing in the domestic area through daily living activities in the family. It turned out that, despite the COVID-19 pandemic, the subjects were still unaware of the importance of conditioning home as a means for children with ID to learn social skills. This suggests the need for solutions in relation to the situation and condition in a family which is conducive for the children with ID's social skills learning during the COVID-19. The pandemic caused problems not only to children's health but also to their development (Nature, 2020).

According to the subjects, nurturing some social skills required media in which the children would gather or mingle with others (closest ones). This statement is true because social development would determine the children's preparation for life in society (Garrote et al., 2017). Children with ID need concrete behavioural examples from others in social skills, which are abstract. These skills include those in the desire for social acceptance, sympathy, empathy, and emulation categories. This phenomenon suggests that children with ID need connectivity to the symbolism behind the things they learn (LussierDesrochers et al., 2014; Mamta Rani \& Hemant Singh Keshwal, 2016). The forms of nurturing mentioned by the subjects were consistent with those mentioned in previous research, but whether daily living activities in family function as a means for social skills nurturing has yet to be answered.

Competitive skills are a group of skills that are case-based. This is to be understood in the sense that only a few parents saw these skills as those needed nurturing. Competitive skills actually are useful during adulthood for the children to actualize their roles in society. These social skills are useful for the preparation for adult life (Domitrovich et al., 2017; Smith et al., 2012). Competitive skills for children with ID should be trained in a wider, general community context, allowing them to directly be trained to play a role meaningfully in a wider environment. The children with ID would immediately experience failure or success.

Family's Nurturing inclination of some social skills is very important for children with ID to interact or gather with others because these skills are meant to be useful in collective life. Regarding forms of nurturing, the subjects would get their children to play with their siblings and neighbouring peers. One subject assigned his/her child to sweep the floor, while two other subjects said that their children would study with them. The subjects will not have competitive skills to be developed. Nurturing would need concrete exemplification and habituation. The children would mingle with the social groups closest to them. Some skills were abstract in nature. Hence these skills should be learnt in relevant social situations. The children would emulate the events or deeds occurring around them. These social skills do not go well with social distancing, which is enacted to prevent COVID-19 transmissions. Therefore, the state- 
ments of the eight subjects have yet to provide an alternative in the case of social distancing implementation. To overcome this problem, schools must provide parents with training in nurturing social skills through daily living activities in the family (Rani \& Keshwal, 2016; Yoshikawa et al., 2020). Facilitating the nurturing of the social skills development of children with ID need concrete examples in relevant social situations (i.e., nurturing would need other individuals to set an example). This is an appropriate nurturing way in the case of children with ID (Shepley et al., 2018). Children with ID encounter difficulties in learning something abstract, hence needing concrete examples to learn social skills. Therefore, the family should facilitate their learning through daily living activities in the family (Barker, 2008; King et al., 2017). The findings from the interviews with the subjects have yet to confirm the family's alternative role in social skills nurturing during the COVID19.

Intensities in the nurturing of social skills development of early-age children with ID were case-based. Abstract skills such as sympathizing and empathizing skills were not intensively trained for children with ID. The skills that were more intensively nurtured were cooperative skills. Intensive training was not possible in the categories of generosity, unselfishness, and emulation without the presence of other individuals to play their roles in social contexts. This suggests that the social skills of children with ID require nurturing, and due to their limited cognitive abilities, these children need direct examples and encouragement in relevant situations. Behavioural problems also accompany children's with ID condition, necessitating strong social skills nurturing efforts on the part of the parents (Blacher et al., 2009).

\section{CONCLUSION}

Parents' nurturing in the social skills of children with ID during the COVID-19 pandemic are conducted through activities like playing, sharing toys in various activities and food, mingling in closest communities, emulating the behaviours of closest ones, sympathizing with the predicaments of others, and reading others' facial expressions. Nurturing these skills requires concrete examples and relevant social situations (i.e., nurturing would need other individuals to set an example). This explains the lower intensity of training in social skills categories which are abstract in nature, namely, sympathy and empa- thy. The parents' nurturing through domestic activities in the family was conducted minimally. Therefore, it is necessary for special needs schools to cooperate with parents to nurture the social skills of children with ID through daily living activities in family.

\section{REFERENCES}

Adela, M., Mihaela, S., Elena-Adriana, T., \& Monica, F. (2011). Evaluation of a program for developing socio-emotional competencies in pre-school children. Procedia - Social and Behavioral Sciences, 30, 2161-2164. https://doi.org/10.1016/j.sbspro.2011.10.4 19

Allen, D. (2008). The relationship between challenging behaviour and mental illhealth in people with intellectual disabilities: A review of current theories and evidence. Journal of Intellectual Disabilities, 12(4), 267-294. https://doi.org/10.1177/174462950810049 4

Berns, R. (2010). Child, family, school, community: Socialization and support. Cengage Learning.

Blacher, J., Baker, B. L., \& Eisenhower, A. S. (2009). Student-teacher relationship stability across early school years for children with intellectual disability or typical development. American Journal on Intellectual and Developmental Disabilities, 114(5), 322-339. https://doi.org/10.1352/1944-7558114.5.322

Boehm, T. L., \& Carter, E. W. (2016). A systematic review of informal relationships among parents of individuals with intellectual disability or autism. Research and Practice for Persons with Severe Disabilities, 41(3), 173-190. https://doi.org/10.1177/154079691665733 9

Callahan, K., Hughes, H. L., Mehta, S., Toussaint, K. A., Nichols, S. M., Ma, P. S., Kutlu, M., \& Wang, H.-T. (2017). Social validity of evidence-based practices and emerging interventions in autism. Focus on Autism and Other Developmental Disabilities, 32(3), 188197. https://doi.org/10.1177/108835761663244 6 
Denzin, N. K., \& Lincoln, Y. S. (2008). Collecting and interpreting qualitative materials. Sage.

Dewi, Y. T., Apsari, N. C., Wibhawa, B., \& Humaedi, S. (2018). Activity daily living (ADL) of young people with intellectual disabilities. Proceedings of the International Conference on Diversity and Disability Inclusion in Muslim Societies (ICDDIMS 2017), 153(Icddims 2017), 40-43. https://doi.org/10.2991/icddims17.2018 .9

Diana, R. R., Chirzin, M., Bashori, K., Suud, F. M., \& Khairunnisa, N. Z. (2021). Parental engagement on children character education: The influences of positive parenting and agreeableness mediated by religiosity. Cakrawala Pendidikan, 40(2), 428-444.

https://doi.org/10.21831/cp.v40i2.39477

Domitrovich, C. E., Durlak, J. A., Staley, K. C., \& Weissberg, R. P. (2017). SocialEmotional competence: An essential factor for promoting positive adjustment and reducing risk in school children. Child Development, 88(2), 408-416. https://doi.org/10.1111/cdev.12739

Ferreira, M., Aguiar, C., Correia, N., Fialho, M., $\&$ Pimentel, J. S. (2019). Friendships and social acceptance of portuguese children with disabilities: The role of classroom quality, individual skills, and dosage. Topics in Early Childhood Special Education, 39(3), 183-195. https://doi.org/10.1177/027112141986441 9

Garrote, A., Sermier Dessemontet, R., \& Moser Opitz, E. (2017). Facilitating the social participation of pupils with special educational needs in mainstream schools: A review of school-based interventions. Educational Research Review, 20, 12-23. https://doi.org/10.1016/j.edurev.2016.11.0 01

Hallam, S. (2010). The power of music: Its impact on the intellectual, social and personal development of children and young people. International Journal of Music Education, 28(3), 269-289. https://doi.org/10.1177/025576141037065 8

Halle, T. G., \& Darling-Churchill, K. E. (2016). Review of measures of social and emotional development. Journal of

Applied Developmental Psychology, 45, 8-18.

https://doi.org/10.1016/j.appdev.2016.02.0 03

Hardman, M. L., Egan, M. W., Drew, C. J., Taylor, T., Brigham, D., Gibb, G. S., \& Young, B. (2016). Human exceptionality: School, community, and family. Cengage Learning.

Hurlock, E. B. (2001). Child development (6th ed.). McGraw-Hill.

King, E., Okodogbe, T., Burke, E., McCarron, M., McCallion, P., \& O'Donovan, M. A. (2017). Activities of daily living and transition to community living for adults with intellectual disabilities. Scandinavian Journal of Occupational Therapy, 24(5), 357-365.

https://doi.org/10.1080/11038128.2016.12 27369

Lussier-Desrochers, D., Lachapelle, Y., \& Caouette, M. (2014). Challenges in the completion of daily living activities in residential settings. Journal on Developmental Disabilities, 20(1), 16. https://oadd.org/wpcontent/uploads/2014/01/41017_JoDD_20 -1_v11f_16-24_LussierDesrochers_et_al.pdf

Mamta Rani, \& Hemant Singh Keshwal. (2016). Effect of Co-curricular Activities on Development of Social Skills of Children with Intellectual Disability. Journal of Disability Management and Rehabilitation, 2(1), 18-21.

McLeod, B. D., Sutherland, K. S., Martinez, R. G., Conroy, M. A., Snyder, P. A., \& Southam-Gerow, M. A. (2017). Identifying Common Practice Elements to Improve Social, Emotional, and Behavioral Outcomes of Young Children in Early Childhood Classrooms. Prevention Science, 18(2), 204-213. https://doi.org/10.1007/s11121-016-0703$\mathrm{y}$

Mihaela, T. I. (2015). Promoting The Emotional Wellbeing of Preschoolers. Procedia Social and Behavioral Sciences, 209(July), 509-513. https://doi.org/10.1016/j.sbspro.2015.11.2 80

Mujahidah, N. E., Astuti, B., \& Nhung, L. N. A. 
(2019). Decreasing academic stress through problem-focused coping strategy for junior high school students. Psychology, Evaluation, and Technology in Educational Research, 2(1), 1-9. https://doi.org/10.33292/petier.v2i1.25

Muthmainah, Purwanta, E., Suwarjo, \& Mariani. (2021). Coping strategies among kindergarteners in the gender perspective. Cakrawala Pendidikan, 40(2), 316-328. https://doi.org/10.21831/cp.v40i2.39359

Nastiti, R. B., \& Purwanta, E. (2019). Introducing career to kindergarten students. Psychology, Evaluation, and Technology in Educational Research, 2(1), 10. https://doi.org/10.33292/petier.v2i1.29

Nature, S. (2020). Impact of the Covid-19 Pandemic on Early Childhood Care and Education. In Early Childhood Education Journal (Vol. 48, Issue 5, pp. 533-536).

Piek, J. P., Dawson, L., Smith, L. M., \& Gasson, N. (2008). The role of early fine and gross motor development on later motor and cognitive ability. Human Movement Science, 27(5), 668-681. https://doi.org/10.1016/j.humov.2007.11.0 02

Rock, L., \& Crow, S. (2017). Not just "soft skills": How young children's learning \& health benefit from strong socialemotional development. Opportunity Institute.

Shepley, S. B., Spriggs, A. D., Samudre, M., \& Elliot, M. (2018). Increasing daily living independence using video activity schedules in middle school students with intellectual disability. Journal of Special Education Technology, 33(2), 71-82. https://doi.org/10.1177/016264341773229 4

Smith, L. E., Maenner, M. J., \& Seltzer, M. M. (2012). Developmental trajectories in adolescents and adults with autism: The case of daily living skills. Journal of the American Academy of Child and Adolescent Psychiatry, 51(6), 622-631. https://doi.org/10.1016/j.jaac.2012.03.001

Spriggs, A. D., Mims, P. J., van Dijk, W., \& Knight, V. F. (2017). Examination of the evidence base for using visual activity schedules with students with intellectual disability. The Journal of Special
Education, 51(1), 14-26.

https://doi.org/10.1177/002246691665848 3

Sterkenburg, P., Schuengel, C., \& Janssen, C. (2008). Developing a therapeutic relationship with a blind client with a severe intellectual disability and persistent challenging behaviour. Disability and Rehabilitation, 30(17), 1318-1327. https://doi.org/10.1080/096382807014825 97

Tarasova, K. S. (2016). Development of socioemotional competence in primary school children. Procedia - Social and Behavioral Sciences, 233(May), 128-132. https://doi.org/10.1016/j.sbspro.2016.10.1 66

Tassé, M. J., Schalock, R. L., Balboni, G., Bersani, H., Borthwick-Duffy, S. A., Spreat, S., Thissen, D., Widaman, K. F., $\&$ Zhang, D. (2012). The construct of adaptive behavior: Its conceptualization, measurement, and use in the field of intellectual disability. American Journal on Intellectual and Developmental Disabilities, 117(4), 291-303. https://doi.org/10.1352/1944-7558117.4.291

Taylor, R. D., Oberle, E., Durlak, J. A., \& Weissberg, R. P. (2017). Promoting positive youth development through school-based social and emotional learning interventions: A meta-analysis of follow-up effects. Child Development, 88(4), 1156-1171. https://doi.org/10.1111/cdev.12864

Tudor, M. E., \& Lerner, M. D. (2015). Intervention and support for siblings of youth with developmental disabilities: A systematic review. Clinical Child and Family Psychology Review, 18(1), 1-23. https://doi.org/10.1007/s10567-014-01751

Vuijk, P. J., Hartman, E., Scherder, E., \& Visscher, C. (2010). Motor performance of children with mild intellectual disability and borderline intellectual functioning. Journal of Intellectual Disability Research, 54(11), 955-965. https://doi.org/10.1111/j.13652788.2010.01318.x

Yoshikawa, H., Wuermli, A. J., Britto, P. R., Dreyer, B., Leckman, J. F., Lye, S. J., 
Ponguta, L. A., Richter, L. M., \& Stein, A. (2020). Effects of the global coronavirus disease-2019 pandemic on early childhood development: Short- and long-term risks and mitigating program and policy actions. The Journal of Pediatrics, 223(September), 188-193.

https://doi.org/10.1016/j.jpeds.2020.05.02 0 